\section{UF 44-4: A Dwarf Red Lance-leaved Caladium Cultivar}

\author{
Zhanao Deng ${ }^{1}$ and Brent K. Harbaugh \\ University of Florida/IFAS, Environmental Horticulture Department, Gulf \\ Coast Research and Education Center, 14625 County Road 672, Wimauma, \\ FL 33598
}

Additional index words. Caladium $\times$ hortulanum, foliage, ornamental breeding, Caladium bicolor, Araceae

Cultivated caladiums (Caladium $\times$ hortulanum Birdsey) are valued for their bright colorful leaves (Evans et al., 1992). They can be broadly classified into three groups based on leaf shape: fancy, lance, and strap (Deng and Harbaugh, 2006; Wilfret, 1986). Fancy-leaved caladiums have heart-shaped leaves with three main veins, petiole attachment peltate, and they have two large basal lobes. Strap-leaved caladiums have narrow, linear leaves with one main vein and no obvious basal lobes. Lance leaves are intermediate between fancy and strap types with leaf blades that are broad sagittate to cordatelanceolate. Basal lobes on different lanceleaved cultivars range from obvious to barely visible.

In addition to leaf shape, lance-leaved caladiums differ from fancy-leaved caladiums in a number of plant, foliar, and tuber characteristics. Plants of lance-leaved caladiums are generally shorter and have thicker and denser leaves than fancy-leaved caladiums. Tubers are more branched, and main eyes are less dominant over secondary eyes compared with fancyleaved cultivars. De-eyeing (removal or destruction of the main eye or bud on tubers) is generally not necessary when forcing multibranched tubers of lance-leaved caladiums in containers, even in small pots (4 inches in diameter). With a compact growth habit, lance-leaved caladiums are very adaptable to different types and sizes of containers. Shorter and/or smaller pot plants are easier and less expensive to ship. Lance-leaved caladiums also appear to be more resilient to sunburns, wind damage, drought, and shading than fancy-leaved caladiums. These characteristics allow lance-leaved caladiums to perform well in the landscape when such stresses occur.

The majority (greater than 95\%) of caladium tubers used in the United States and abroad are produced in Florida. Florida growers supply as many as 50 to 70 million caladium tubers to greenhouse growers, nurseries, and homeowners throughout the United States and Canada and to some 40 countries in Europe and Asia. The majority of caladium cultivars in commercial production are the fancy-leaved type (Bell et al., 1998; Deng et al., 2005).

Received for publication 14 Apr. 2011. Accepted for publication 17 May 2011.

${ }^{1}$ To whom reprint requests should be addressed; e-mail zdeng@ufl.edu.
However, during the past two or three decades, the demand for lance-leaved cultivars has increased steadily. For example, Florida growers planted greater than $50 \%$ more acres with lance-leaved cultivars in 2003 than in 1998 (Bell et al., 1998; Deng et al., 2005). Lance-leaved cultivars are expected to gain even greater popularity in the future.

UF 44-4 is an attractive lance-leaved cultivar with a novel combination of leaf characteristics (bright red color, slightly undulate, and rounded leaf shape) (Figs. 1 and 2). In replicated field and greenhouse trials, it was comparable or superior to 'Florida Red Ruffles' and 'Florida Sweetheart' (the most popular red lance-leaved commercial cultivar and the most popular lance-leaved cultivar in all colors, respectively) in tuber yield potential, pot plant quality, and landscape performance. UF 44-4 is well suited for producing pot plants and hanging baskets, and de-eyeing is not required for forcing in small- or medium-sized containers (11.4 to $15.3 \mathrm{~cm})$.

\section{Origin}

UF 44-4 was selected in 2001 from a population of progeny resulting from selfing S79206, a caladium selection from cross-pollinating 'Candidum Junior' and 'Red Frill', two unpatented commercial cultivars. 'Candidum Junior' is fancy-leaved, whereas 'Red Frill' is lance-leaved. They were selected as parents for plants.

\section{Description}

Descriptions of color [e.g., Royal Horticultural Society (RHS) 200B] for plant parts are based on comparison with the Royal Horticultural Society Color Chart (Royal Horticultural Society, 1986). Plants used for describing color were grown in $11.5-\mathrm{cm}$ containers in a $50 \%$ shaded greenhouse from No. 1 (3.8 to $6.4 \mathrm{~cm}$ ) de-eyed tubers.

On the upper surface of UF 44-4 leaves, a dark green (RHS 139B) margin, up to $15 \mathrm{~mm}$ wide, borders the entire leaf except for the basal leaf valley where it is grayed purple (RHS 187C). The leaf center is a grayed purple (RHS 187C). As many as 16 large, grayed purple (RHS 185A) veins radiate from a central main vein of grayed purple (RHS 185A) and connect marginally with a thin grayed purple their excellent growth habit as pot or landscape vein (RHS 184A) that parallels the leaf margin. Irregular yellow-green mottling (RHS 147A) parallels the margin.

The leaf undersurface has a yellow-green (RHS 147B) margin up to $20 \mathrm{~mm}$ wide, a red-purple (RHS 59B) center, and red-purple (RHS 59A) veins. The center and veins are covered with grayed white (RHS 156C) wax. Irregular yellow-green (RHS 147B) mottling, up to $30 \mathrm{~mm}$ wide, parallels the margin.

Petioles are 3 to $5 \mathrm{~mm}$ and grayed purple (RHS 184A) at the apex, and the colors diffuse into a light grayed purple (RHS 183C) at the base that is $\approx 8 \mathrm{~mm}$ in diameter. The upper portion of the petiole below the apex is frequently covered with a gray-white color (RHS $156 \mathrm{C}$ ), and the low portion of the petiole shows a dense distribution of light brown (RHS 200C) speckles.

UF 44-4 plants grown for $\approx 4$ months in full sun in ground beds had an average height of $\approx 30 \mathrm{~cm}$. Leaves are sagitate-cordate, $\approx 19.2 \mathrm{~cm}$ long and $12.7 \mathrm{~cm}$ wide, and slightly undulate. Jumbo tubers are multisegmented, bearing six to nine dominant buds. Tuber surfaces are brown (RHS 200D) with the cortical area yellow-orange (RHS 15D).

\section{Performance}

UF 44-4 was evaluated for tuber production and plant performance at the Gulf Coast Research and Education Center in Wimauma, FL, in 2005 and 2006. The soil was an EauGallie fine sand with $\approx 1 \%$ organic matter and a $\mathrm{pH}$ of 6.2. Plants were grown in a plastic-mulched raised-bed system maintaining a constant water table with seep irrigation (Geraldson et al., 1965). In 2005, ground beds were fumigated on 25 Feb. (6 weeks before planting) with a mixture of $67 \%$ methyl bromide and 33\% chloropicrin (by volume) at the rate of $392 \mathrm{~kg} \cdot \mathrm{ha}^{-1}$, and in 2006 , the beds were fumigated on $10 \mathrm{Mar}$., $10 \mathrm{~d}$ before planting, with the same fumigant mixture but at the half rate, $196 \mathrm{~kg} \cdot \mathrm{ha}^{-1}$. The beds were $91 \mathrm{~cm}$ wide and $20 \mathrm{~cm}$ high with $2.54-\mathrm{cm}$ caladium seed pieces (tuber pieces) planted $15 \mathrm{~cm}$ apart in three rows. Osmocote $18 \mathrm{~N}-2.6 \mathrm{P}-$ 10K 8-9 month controlled-release fertilizer (Scotts Co., Marysville, $\mathrm{OH}$ ) was applied to the bed surface when shoot tips were emerging from the soil with nitrogen at $336 \mathrm{~kg} \cdot \mathrm{ha}^{-1}$.

Field plots were organized in a randomized complete block design consisting of three replications. For tuber production, each plot was $1.2 \mathrm{~m}^{2}$ and contained 30 propagules $\left(\approx 2.54 \mathrm{~cm}^{3}\right)$. New tubers were harvested in Nov. 2005 and Dec. 2006, respectively. Tubers were dried in the greenhouse for $\approx 4$ weeks and then graded by their maximum diameter: No. 2 (2.5 to $3.8 \mathrm{~cm})$, No. 1 (3.8 to $6.4 \mathrm{~cm})$, Jumbo $(6.4$ to $8.9 \mathrm{~cm})$, Mammoth $(8.9$ to $11.4 \mathrm{~cm})$, and Super Mammoth (greater than $11.4 \mathrm{~cm}$ ). Production index, an indicator of economic value of the harvested tubers, was calculated for each plot as follows: $\mathrm{N}($ No. 2$)+2 \mathrm{~N}($ No. 1$)+4 \mathrm{~N}$ (Jumbo) $+6 \mathrm{~N}$ (Mammoth) $+8 \mathrm{~N}$ (Super Mammoth), in which $\mathrm{N}=$ number of tubers in each grade from each field plot. An analysis of variance was conducted using the general linear 
model provided in SAS (PROC GLM; SAS Institute, 2011) to compare the performance of UF 44-4 with that of 'Florida Red Ruffles' and 'Florida Sweetheart'. 'Red Frill', another commercial red lance-leaf cultivar, was included also as a control in the trials in 2006 and 2007.

In 2005, UF 44-4's tuber weight was $3.7 \mathrm{~kg}$, its production index was 166.8 , and its number of marketable tubers was 64.4 per plot (Table $1)$. Its tuber weight was $23 \%$ greater than 'Florida Red Ruffles' ( $3.0 \mathrm{~kg}$ ) and 12\% greater than 'Florida Sweetheart's $(3.3 \mathrm{~kg})$. The production index for UF $44-4$ was $29 \%$ and $15 \%$ higher than that of 'Florida Red Ruffles' (129.7) and 'Florida Sweetheart' (144.3), respectively. UF $44-4$ produced $58 \%$ and $38 \%$ more tubers than 'Florida Red Ruffles' and 'Florida Sweetheart', respectively.

In 2006, UF 44-4 tuber weight (3.3 kg) was $43 \%$ and $18 \%$ higher than 'Florida Red Ruffles' (2.3 kg) and 'Florida Sweetheart' $(2.8 \mathrm{~kg})$, but the difference was not statistically significant (Table 1). UF 44-4 had 1.75-fold greater tuber weight than 'Red Frill'. In production index and number of marketable tubers, UF 44-4 is comparable to 'Florida Red Ruffles' and 'Florida Sweetheart'. UF 44-4's tuber weight was $\approx 1.8$-fold higher, and production index was $75 \%$ greater than 'Red Frill'.

In tuber grade distribution, the majority ( $55 \%$ or more) of tubers of UF $44-4$ were in the categories of No. 1, Jumbo, or Mammoth, which was similar to the size distribution of 'Florida Red Ruffles' and 'Florida Sweetheart'. UF 44-4 produced more large tubers (Mammoth and Jumbo) than 'Red Frill', which had the majority (greater than 95\%) of tubers in the No. 1 and No. 2 categories.

Landscape performance of UF 44-4 was evaluated on the same plots used for evaluating tuber production. A scale of 1 to 5 was used with 1 being very poor (few leaves and lack of vigor) and 5 being excellent (full plants, numerous leaves, and bright color display). Leaf sunburn tolerance also was evaluated on a scale of 1 to 5 with 1 being very susceptible to sunburns (leaves having numerous sun-damaged areas or holes) and 5 being resistant to sunburns (no visible sun-damaged areas). A total of eight evaluations was conducted for plant performance and sunburn tolerance over three growing seasons in June, July, and Aug. 2005, Aug. and Sept. 2006, and July, Aug., and Sept. 2007. Approximately 4 months after planting, plant height, number of leaves, and leaf size were measured on three randomly chosen plants in each plot.

Plants of UF 44-4 were 6 to $8 \mathrm{~cm}$ taller than those of 'Florida Red Ruffles' and 'Florida Sweetheart' (Table 2). Leaf width of UF 44-4 was similar to that of 'Florida Sweetheart' but $\approx 2 \mathrm{~cm}$ wider than that of 'Florida Red Ruffles'. The most significant difference among the entries was in the leaf number produced per plant: 42.7 by UF $44-4$ versus 20.9 to 26.3 by 'Florida Red Ruffles', 'Florida Sweetheart', or 'Red Frill', respectively (Table 2). With this many leaves, UF 44-4 produced full plants with bright color display and received the highest ratings for plant performance: 3.4 to 3.5 in June 2005 and Aug. 2006; 4.0 in Sept.

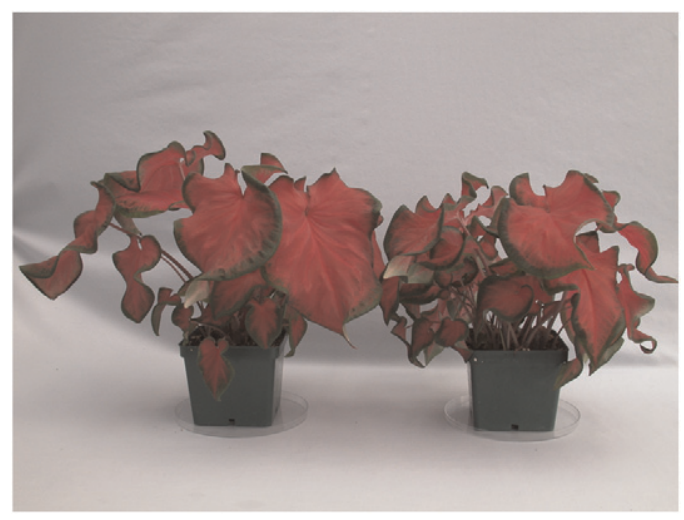

Fig. 1. UF 44-4 plants produced by forcing tubers in 11.4-cm square pots. The plant on the left side was forced from one intact No.1 tuber (3.6 to $6.4 \mathrm{~cm}$ in diameter), whereas the plant on the right side from one de-eyed No. 1 tuber. Photograph was taken 8 weeks after the tuber was planted in the pot.

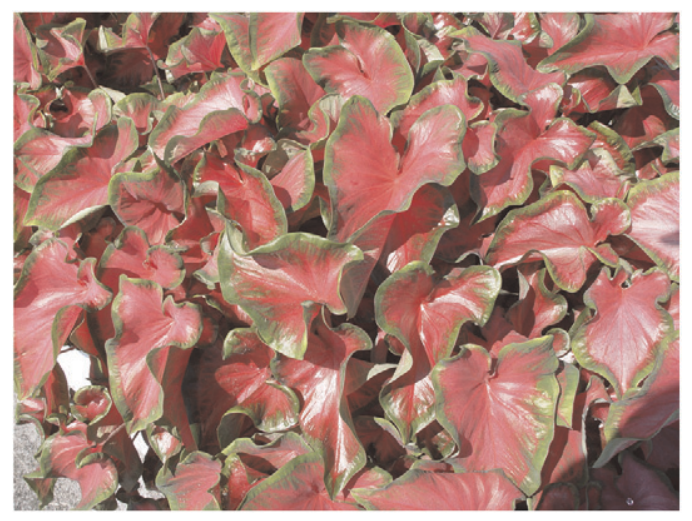

Fig. 2. UF 44-4 plants grown in a ground bed in full sun.

Table 1. Weight, production index, marketable number, and grade distribution of caladium tubers produced in 2005 and 2006 from $302.54-\mathrm{cm}$ tuber propagules planted in a $1.2-\mathrm{m}^{2}$ plot. $^{\mathrm{z}}$

\begin{tabular}{|c|c|c|c|c|c|c|c|c|}
\hline \multirow[b]{2}{*}{ Cultivar } & \multicolumn{3}{|c|}{ Tuber } & \multicolumn{5}{|c|}{ Tuber grade distribution $(\%)^{y}$} \\
\hline & $\begin{array}{c}\mathrm{Wt} \\
(\mathrm{kg})\end{array}$ & $\begin{array}{l}\text { Production } \\
\text { index }\end{array}$ & $\begin{array}{c}\text { Marketable } \\
\text { (no.) }\end{array}$ & $\begin{array}{c}\text { Super } \\
\text { mammoth }\end{array}$ & Mammoth & Jumbo & No. 1 & No. 2 \\
\hline \multicolumn{9}{|c|}{ 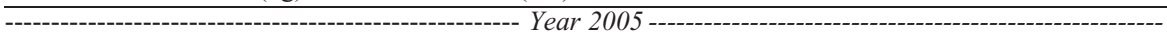 } \\
\hline UF $44-4$ & $3.7 \mathrm{a}^{\mathrm{w}}$ & $166.8 \mathrm{a}$ & $64.4 \mathrm{a}$ & 0 & 7.0 & 28.1 & 39.7 & 25.1 \\
\hline Florida Red Ruffles & $3.0 \mathrm{~b}$ & $129.7 \mathrm{c}$ & $40.7 \mathrm{~b}$ & 0.8 & 15.6 & 35.2 & 33.1 & 15.2 \\
\hline Florida Sweetheart & $3.3 \mathrm{~b}$ & $144.3 \mathrm{~b}$ & $46.7 \mathrm{~b}$ & 2.8 & 17.9 & 24.7 & 27.1 & 27.5 \\
\hline $\operatorname{LSD}(\alpha=0.05)$ & 0.4 & 11.3 & 7.1 & NS & NS & NS & NS & NS \\
\hline & & & - Year 2 & & & & & \\
\hline UF $44-4$ & $3.3 \mathrm{a}$ & $118.6 \mathrm{a}$ & 49.7 & 2.5 & 7.1 & $17.5 \mathrm{a}$ & $42.8 \mathrm{ab}$ & 30.0 \\
\hline Florida Red Ruffles & $2.3 \mathrm{a}$ & $87.9 \mathrm{ab}$ & 43.8 & 0 & 6.5 & $19.7 \mathrm{a}$ & $30.1 \mathrm{~b}$ & 42.7 \\
\hline Florida Sweetheart & $2.8 \mathrm{a}$ & $111.0 \mathrm{a}$ & 48.6 & 0.9 & 3.1 & $20.7 \mathrm{a}$ & $49.1 \mathrm{ab}$ & 27.2 \\
\hline Red Frill & $1.2 \mathrm{~b}$ & $67.7 \mathrm{~b}$ & 38.8 & 0 & $0 \mathrm{~b}$ & $1.4 \mathrm{~b}$ & $66.8 \mathrm{a}$ & 31.9 \\
\hline $\operatorname{LSD}(\alpha=0.05)$ & 1.1 & 31.0 & NS & NS & NS & 7.2 & 27.4 & NS \\
\hline
\end{tabular}

${ }^{\mathrm{z}}$ Values presented are means of three replications in each year.

${ }^{\mathrm{y}}$ Tubers graded by maximum diameter; No. 2 (2.5 to $\left.3.8 \mathrm{~cm}\right)$, No. $1(3.8$ to $6.4 \mathrm{~cm})$, Jumbo $(6.4$ to $8.9 \mathrm{~cm})$, Mammoth (8.9 to $11.4 \mathrm{~cm})$, and Super Mammoth (greater than $11.4 \mathrm{~cm}$ ).

${ }^{\mathrm{x}}$ The production index is an indicator of economic value of the crop harvested and is calculated as: $\mathrm{N}$ $($ No. $2 \mathrm{~s})+2 \mathrm{~N}$ (No. 1s) $+4 \mathrm{~N}$; (Jumbos) $+6 \mathrm{~N}$ (Mammoth) $+8 \mathrm{~N}($ Super Mammoth) in which $\mathrm{N}=$ number of tubers in each grade.

${ }^{\text {w}}$ Mean separation within columns by Fisher's least significant difference (LSD) test at $P \leq 0.05$. NS Non-significantly different at $P \leq 0.05$.

Table 2. Plant characteristics of UF 44-4 and three commercial cultivars $\approx 4$ months from planting $2.54-\mathrm{cm}$ tuber propagules in ground beds in full sun in 2005 and $2006 .^{\mathrm{z}}$

\begin{tabular}{lcccc}
\hline \multicolumn{1}{c}{ Cultivar } & Plant ht $(\mathrm{cm})$ & Leaves $($ no. $)$ & Leaf length $(\mathrm{cm})$ & Leaf width $(\mathrm{cm})$ \\
\hline UF 44-4 & $30.1 \mathrm{a}^{\mathrm{y}}$ & $42.7 \mathrm{a}$ & $19.2 \mathrm{a}$ & $12.7 \mathrm{a}$ \\
Florida Red Ruffles & $21.9 \mathrm{~b}$ & $26.3 \mathrm{~b}$ & $18.2 \mathrm{a}$ & $10.7 \mathrm{~b}$ \\
Florida Sweetheart & $24.2 \mathrm{~b}$ & $21.5 \mathrm{~b}$ & $20.0 \mathrm{a}$ & $13.3 \mathrm{a}$ \\
Red Frill & $14.3 \mathrm{c}$ & $20.9 \mathrm{~b}$ & $14.8 \mathrm{~b}$ & $7.9 \mathrm{c}$ \\
LSD $(\alpha=0.05)$ & 4.7 & 10.9 & 3.0 & 1.5 \\
\hline
\end{tabular}

${ }^{\mathrm{z}}$ Values presented are means of three replications with three plants measured per plot per year.

${ }^{\mathrm{y}}$ Mean separation within columns by Fisher's least significant difference (LSD) test at $P \leq 0.05$. 
Table 3. Plant performance and sun burn tolerance of UF 44-4 and three commercial cultivars when planted in ground beds in full sun in 2005, 2006, and 2007.

\begin{tabular}{|c|c|c|c|c|c|c|c|c|c|c|c|c|c|c|c|c|}
\hline \multirow[b]{3}{*}{ Cultivar } & \multicolumn{8}{|c|}{ Performance rating ${ }^{y}$} & \multicolumn{8}{|c|}{ Sun tolerance rating ${ }^{x}$} \\
\hline & \multicolumn{3}{|c|}{2005} & \multicolumn{2}{|c|}{2006} & \multicolumn{3}{|c|}{2007} & \multicolumn{3}{|c|}{2005} & \multicolumn{2}{|c|}{2006} & \multicolumn{3}{|c|}{2007} \\
\hline & June & July & Aug. & Aug. & Sept. & July & Aug. & Sept. & June & July & Aug. & Aug. & Sept. & July & Aug. & Sept. \\
\hline UF 44-4 & $3.4 \mathrm{a}^{\mathrm{w}}$ & $4.7 \mathrm{a}$ & $4.8 \mathrm{a}$ & $3.5 \mathrm{a}$ & $4.0 \mathrm{a}$ & $4.0 \mathrm{ab}$ & $4.0 \mathrm{a}$ & $4.0 \mathrm{a}$ & 3.5 & 4.7 & 4.5 & 3.8 & $4.3 \mathrm{ab}$ & 3.7 & $4.6 \mathrm{a}$ & $4.0 \mathrm{a}$ \\
\hline Florida Red Ruffles & $2.8 \mathrm{ab}$ & $4.1 \mathrm{ab}$ & $4.3 \mathrm{~b}$ & $2.0 \mathrm{~b}$ & $3.0 \mathrm{~b}$ & $3.8 \mathrm{ab}$ & $3.1 \mathrm{~b}$ & $2.9 \mathrm{ab}$ & 3.6 & 4.4 & 4.3 & 4.0 & $4.7 \mathrm{a}$ & 3.5 & $4.3 \mathrm{a}$ & $4.0 \mathrm{a}$ \\
\hline Florida Sweetheart & $2.6 \mathrm{~b}$ & $3.8 \mathrm{~b}$ & $4.1 \mathrm{~b}$ & $3.3 \mathrm{a}$ & $4.0 \mathrm{a}$ & $3.3 \mathrm{~b}$ & $3.1 \mathrm{~b}$ & $2.8 \mathrm{~b}$ & 3.0 & 4.1 & 4.2 & 4.0 & $4.6 \mathrm{a}$ & 3.5 & $4.3 \mathrm{a}$ & $3.8 \mathrm{a}$ \\
\hline Red Frill & $-^{\mathrm{v}}$ & - & - & $2.5 \mathrm{~b}$ & $2.5 \mathrm{~b}$ & $4.2 \mathrm{a}$ & $2.8 \mathrm{~b}$ & $2.0 \mathrm{~b}$ & - & - & - & 3.8 & $4.2 \mathrm{~b}$ & 3.8 & $3.4 \mathrm{~b}$ & $2.3 \mathrm{~b}$ \\
\hline $\operatorname{LSD}(\alpha=0.05)$ & 0.7 & 0.8 & 0.4 & 1.3 & 0.5 & 0.8 & 0.6 & 1.1 & $\mathrm{NS}^{\mathrm{u}}$ & NS & NS & NS & 0.3 & NS & 0.7 & 0.3 \\
\hline
\end{tabular}

${ }^{\mathrm{z}}$ Values presented are means of three replications in each year.

${ }^{y}$ Plants were rated on a scale of 1 to 5 with 1 being very poor, 3 fair and acceptable, and 5 being excellent in plant vigor, fullness, and color display.

'Plants' sunburn tolerance was rated on a scale of 1 to 5 with 1 being very poor, 3 fair and acceptable, and 5 being excellent without showing any signs of leaf burns or holes caused by sunburn on leaf surfaces.

${ }^{\text {w }}$ Mean separation within columns by Fisher's least significant difference (LSD) test at $P \leq 0.05$.

${ }^{\mathrm{v}}$ This cultivar was not included in the trial in 2005.

"NS Non-significantly different at $P \leq 0.05$.

Table 4. Plant performance for caladium cultivars grown from No. 1 tubers in $11.4-\mathrm{cm}$ containers in a $45 \%$ shaded glasshouse in Wimauma, FL, $2007 .{ }^{2}$

\begin{tabular}{|c|c|c|c|c|c|c|c|c|c|c|c|c|}
\hline \multirow[b]{2}{*}{ Cultivar } & \multicolumn{2}{|c|}{ Days to sprout ${ }^{\mathrm{y}}$} & \multicolumn{2}{|c|}{ Plant ht $(\mathrm{cm})$} & \multicolumn{2}{|c|}{ Leaves (no.) } & \multicolumn{2}{|c|}{ Leaf length $(\mathrm{cm})$} & \multicolumn{2}{|c|}{ Leaf width $(\mathrm{cm})$} & \multicolumn{2}{|c|}{ Quality rating } \\
\hline & Intact & De-eye & Intact & $\overline{\text { De-eye }}$ & Intact & $\overline{\text { De-eye }}$ & Intact & De-eye & Intact & De-eye & Intact & De-eye \\
\hline UF 44-4 & $38.6 \mathrm{ab}^{\mathrm{x}}$ & $38.0 \mathrm{a}$ & $16.3 \mathrm{a}$ & $14.4 \mathrm{a}$ & 10.0 & 17.2 & 16.2 & $16.4 \mathrm{a}$ & 12.1 & $10.3 \mathrm{~b}$ & $4.1 \mathrm{a}$ & $4.5 \mathrm{a}$ \\
\hline Florida Red Ruffles & $36.8 \mathrm{~b}$ & $39.6 \mathrm{a}$ & $16.1 \mathrm{a}$ & $16.6 \mathrm{a}$ & 9.4 & 13.3 & 17.7 & $17.5 \mathrm{a}$ & 12.5 & $12.3 \mathrm{a}$ & $3.5 \mathrm{~b}$ & $4.1 \mathrm{ab}$ \\
\hline Florida Sweetheart & $42.3 \mathrm{a}$ & $40.0 \mathrm{a}$ & $17.3 \mathrm{a}$ & $16.2 \mathrm{a}$ & 10.9 & 14.8 & 17.5 & $16.4 \mathrm{a}$ & 10.9 & $10.6 \mathrm{ab}$ & $3.2 \mathrm{bc}$ & $4.0 \mathrm{~b}$ \\
\hline Red Frill & $30.9 \mathrm{c}$ & $31.5 \mathrm{~b}$ & $10.8 \mathrm{~b}$ & $11.3 \mathrm{~b}$ & 10.8 & 16.7 & 15.1 & $14.1 \mathrm{~b}$ & 10.7 & $9.9 \mathrm{~b}$ & $2.8 \mathrm{c}$ & $3.9 \mathrm{~b}$ \\
\hline $\operatorname{LSD}(\alpha=0.05)$ & 4.5 & 4.4 & 3.1 & 2.4 & NS & $\mathrm{NS}^{\mathrm{w}}$ & NS & 1.8 & NS & 1.9 & 0.5 & 0.4 \\
\hline
\end{tabular}

${ }_{\mathrm{z}}^{\mathrm{z}}$ alues represent the means of 10 plants produced from intact or de-eyed No. 1 (greater than 3.8 and less than $6.4 \mathrm{~cm}$ in diameter) tubers planted individually per container.

${ }^{\mathrm{y}}$ Number of days from planting to the first unfurled leaf.

${ }^{x}$ Mean separation within columns by Fisher's least significant difference (LSD) test at $P \leq 0.05$.

${ }^{\text {w }}$ NS Non-significantly different at $P \leq 0.05$.

2006 and July, Aug., and Sept. 2007; and 4.7 to 4.8 in July and Aug. 2005 (Table 3). UF 44-4's plant performance rating was significantly higher than that of 'Florida Red Ruffles' in four of eight evaluations and significantly higher than that of 'Florida Sweetheart' in six of eight evaluations. 'Florida Red Ruffles' and 'Florida Sweetheart' are considered to be sunburn-tolerant cultivars. UF 44-4 received similar sunburn tolerance ratings with 'Florida Red Ruffles' and 'Florida Sweetheart' in all eight evaluations in 3 years.

The suitability of UF 44-4 for pot plant production was evaluated by forcing tubers in 11.4-cm containers. No. 1 tubers were planted either intact or de-eyed in a peat/vermiculite mix (VerGro Container Mix A; Verlite, Tampa, FL) on 26 Mar. 2007. The study was conducted in a greenhouse with $45 \%$ light exclusion during the summer in Wimauma, FL. Average daily temperatures ranged from a low of $16^{\circ} \mathrm{C}$ at night to $29{ }^{\circ} \mathrm{C}$ during the day during the experiment. Potted plants were arranged on metal benches in the greenhouse in a randomized complete block design with 10 replications. Plant height, number of leaves, and foliar characteristics were recorded 8 weeks after planting.

UF 44-4 produced high-quality pot plants regardless of tuber treatments (intact or deeyed) (Table 4). When tubers were planted intact, UF 44-4 sprouted $\approx 39 \mathrm{~d}$ after planting, which was similar to the sprouting time of 'Florida Red Ruffles' and 'Florida Sweetheart' but $\approx 8 \mathrm{~d}$ later than 'Red Frill'. Tuber de-eyeing did not cause any change in sprouting time in UF 44-4. Intact plants of UF 44-4, 'Florida Red Ruffles', and 'Florida Sweetheart' were similar in plant height (14.4 to $17.3 \mathrm{~cm}$ ), numbers $(9.4$ to 10.8 ) of leaves, leaf lengths (16.2 to 17.7 $\mathrm{cm})$, and widths $(10.9$ to $12.1 \mathrm{~cm})$. When plants were de-eyed, UF 44-4, 'Florida Red Ruffles', and 'Florida Sweetheart' were similar in plant height (14.4 to $16.6 \mathrm{~cm}$ ) and number (13.3 to 17.2) of leaves, but UF 44-4's leaves were $\approx 2$ $\mathrm{cm}$ shorter than those of 'Red Ruffles' and 'Florida Sweetheart'. Pot-grown UF 44-4 plants received the highest (4.1 to 4.5 ) quality ratings compared with the three control cultivars (2.8 to 4.1). Quality pot plants were produced without de-eyeing, but de-eyeing appeared to improve plant quality rating (from 4.1 to 4.5 ).

\section{Recommendation}

UF 44-4 is a new lance-leaved cultivar with a novel combination of leaf color and shape (dwarf red with slightly undulated and rounded leaves). Plants of UF 44-4 produce a superb number of bright red leaves in sun or shade and have performed well in replicated container and field trials. UF 44-4 is suitable for a range of container sizes for pot plant production and tubers do not require deeyeing.

Although extensive research and evaluations of these cultivars have been performed on small acreages, growers are encouraged to plant only limited quantities of UF 44-4 until they have gained experience in producing this cultivar. Standard postharvest treatment of tubers is recommended (Harbaugh and Tjia, 1985) and pre-plant hot water treatment of tubers (Rhodes, 1964) is encouraged.

\section{Availability}

A plant patent will be applied for UF 44-4 by the Florida Agricultural Experiment Station and production of this cultivar is to be with a licensing agreement with the Florida Foundation Seed Producers, Inc., P.O. Box 309, Greenwood, FL 32443. Information on tuber availability and propagation agreements can be obtained from the Florida Foundation Seed Producers, Inc.

\section{Literature Cited}

Bell, M.L., G.J. Wilfret, and D.A. DeVoll. 1998. Survey of caladium tuber producers for acreage of cultivars grown. Proc. Fla. State Hort. Soc. 111:32-34.

Deng, Z. and B.K. Harbaugh. 2006. Independent inheritance of leaf shape and main vein color in caladium. J. Amer. Soc. Hort. Sci. 131:53-58.

Deng, Z., B.K. Harbaugh, R.K. Schoellhorn, and R.C. Andrew. 2005. 2003 Survey of the Florida caladium tuber production industry. Univ. of Fla./IFAS extension fact sheet, ENH 1007. 16 Feb. 2008. <http://edis.ifas.ufl.edu/EP258>.

Evans, M.R., G.J. Wilfret, and B.K. Harbaugh. 1992. Caladiums as potted and landscape plants. IFAS, Univ. of Fla. Agr. Ext. Serv. Circ. 1060.

Geraldson, C.M., A.J. Overman, and J.P. Jones. 1965. Combination of high analysis fertilizers, plastic mulch and fumigation for tomato production on old agricultural land. Proc. Soil Crop Sci. Soc. Fla. 25:18-24.

Harbaugh, B.K. and B.O. Tjia. 1985. Commercial forcing of caladiums. IFAS, Univ. of Fla. Agr. Ext. Serv. Circ. 621.

Rhodes, H.L. 1964. Effect of hot water treatment of seed tubers and soil fumigation for control of root knot on yield of caladiums. Plant Disease Reporter 8:568-571.

Royal Horticultural Society. 1986. RHS colour chart. Royal Hort. Soc., London, UK.

SAS Institute. 2011. The SAS system for Windows. Release 9.2. SAS Inst., Cary, NC.

Wilfret, G.J. 1986. Inheritance of leaf shape and color patterns in Caladium (Araceae). HortScience 21:750 (abstr.) 